THE CANADIAN JOURNAL OF

Neurological Sciences

LE JOURNAL CANADIEN DES

Sciences Neurologiques

AN INTERNATIONAL JOURNAL / UN JOURNAL INTERNATIONAL

85 Editorial - Progress in Understanding the Role of Carotid Endarterectomy HJM Barnett and Heather Meldrum

88 Alcoholic Dementia - Review Article Maurice Victor

100 Hippocampal Stimulation of Fornical-lesioned Rats Improves Working Memory $J$ Turnbull, F Jiang and $R$ Racine

104 SPECT for Differential Diagnosis of Dementia and Correlation of rCBF with Cognitive Impairment Alicia Osimani, Masanori Ichise, Dae-Gyun Chung, Janice M Pogue and Morris Freedman

112 Immunological Associations in Familial and Non-Familial Alzheimer Patients and Their Families MF Frecker, WEM Pryse-Phillips and HR Strong

120 Mild Hypothermia Preserves Contractile Function and Inhibits Prostaglandin $\mathrm{E}_{2}$ Release from Metabolically Stressed Skeletal Muscle

Valerie A Cwik, Ramanath Majumdar, Michael H Brooke

125 Usefulness of Single Fiber EMG for Distinguishing Neuromuscular from Other Causes of Ocular Muscle Weakness

C Ukachoke, P Ashby, A Basinski and JA Sharpe

129 Surgical Referral for Carotid Artery Stenosis - The Influence of NASCET $T J$ Coyne and MC Wallace

133 Acute Transverse Myelitis: A Retrospective Study Using Magnetic Resonance Imaging Thomas Scott, Norbert Weikers, Mark Hospodar and Joseph Wapenski

137 Long-Term Results after Glycerol Rhizotomy for Multiple Sclerosis-Related Trigeminal Neuralgia Douglas Kondziolka, L Dade Lunsford and David J Bissonette

141 Unusual Evolution and Computerized Tomographic Appearance of a Gliosarcoma Mark C Preul, Jose A Espinosa, Donatella Tampieri and Stirling Carpenter

\title{
HISTORICAL NEUROLOGY AND NEUROSURGERY
}

146 Neurosurgery at the Toronto General Hospital, 1924-1990: Part 1

$J$ Max Findlay

\section{ABSTRACTS}

159 Abstracts of the 33rd Meeting of the Canadian Association of Neuropathologists, September 3-5, 1993, Whistler, British Columbia

29th CANADIAN CONGRESS OF NEUROLOGICAL SCIENCES June 27 - 30, 1994

St. John's, Newfoundland

\section{SUPPLEMENTS}

Neurocritical Care Symposium, June 1993, Toronto

The official Journal of: The Canadian Neurological Society, The Canadian Neurosurgical Society, The Canadian Society of Clinical Neurophysiologists, The Canadian Association for Child Neurology 

THE CANADIAN JOURNAL OF

\section{Neurological Sciences}

\section{LE JOURNAL CANADIEN DES}

\section{Sciences Neurologiques}

ARTICLES

Historical Nbitrol.ogY ANI NEUROSURCiERY

ABSTRACTS

SUTPLEMENTS
Editorial - Progress in Understanding the Role of Carotid Endarterectomy HJM Barnett and Heather Meldrum

88 Alcoholic Dementia - Review Article Maurice Victor

100 Hippowampal Stimulation of Fornical-lesioned Rats Improves Working Memory I Tumbull, F Jiang and $R$ Racine

104 SPECT for Differential Diagnosis of Dementia and Corrclation of rCBF with Cognitive Impairment Alicia Osimani, Masanori Xchise, Dae-Gvun Chung, Janice M Pogue and Morris liredelman

112 Immunological Associations in lämilial and Non-Familial Nobeimer Patients and Their Fanuilics MF Frecker, WEM Pryse-Phillips and HR Strong

120 Mild Hypothermia Preserves Contractile Function and Inhibits Prostaglandin $\mathrm{E}_{2}$ Release from Metabolically Stressed Skeletal Muscle Valerie A Cwik, Ramanath Majumdar, Michael H Brooke

125 Usefulness of Singlc Fiber EMG for Distinguishing Neuromuscular from Other Causes of Ocular Muscle Weakness C Ukachoke, P Ashby, A Basinski and JA Sharpe

129 Surgical Refertal for Carotid Artery Stenosis - The Influence of NASCE'T TJ Coyne and MC. Wallace

133 Acute Iransverse Myelitis: A Retrospective Study Using Magnetic Resonance Imaging Thomas Scott, Norber! Weikers, Mark Hospodar and Joseph Wapenski

137 Long-7erm Results afler Glycerol Rhizotomy for Multiple Sclerosis-Related Trigeminal Neuraigia Douglas Kondziolka. L. Dade Lunsford and David J Bissonette

141 Unusual Fyolution and Computerized Tonnographic Appearance of a Gliosarcoma Mark C Preul, Jose A Espinosa, Donatella Tumpieri and Stirling Carpenter

146 Neurostrgery at the Toronto General Hospital, 1924-1990: Part 1 J Max Fïndlay

159 Abstracts of the 33rd Meeting of the Canadian Associalion of Neuropathologists, September 3-5, 1993, Whistler, British Columbia

Suppl. 1-\$1 Neurocritical Care Symposium, June 1993, Toronto

Book Reviews 170

Books Received 173

Calender of Events 174

Notes and Announcements $\mathbf{1 7 5}$

Instruclions to Authors iv

Advertisers Index xxiy 
THE CANADIAN JOURNAL OF

Neurological Sciences

LE JOURNAL CANADIEN DES

Sciences Neurologiques

Editor/Rédacteur en chef

James A. Sharpe TORONTO, ON

Associate Editors/Rédacteurs associés

I aurence E. Becker TORONIO, ON

John $P$. Girvin LONDON, ON

Terry W. Picton OTTAWA, ON

Past Editors

Robert G. I.ce CALGARY, AB

Robert T. Ross (founding editor) WINNIPEG, MB

Editorial Board/Conseil Scientifique

Warren T. Blume JONI)ON, ON,

Jean-Pierre Bouchard QUÍlsEC, PQ

Donald B. Calne VAncouver, BC

Peter R. Camfield HaLitinX, NS

Picré Duquette MONTRÉAL, PQ

Peter J. Dyck ROCHESTER, MN, USA

Goorge C. Fbers LONION, ON

Serge Gauthier Mon'tréal, PQ

Julian T. Hoff ANN ARBOR, MI, USA

Pcler Humphreys OTTAWA, ON

Geurge Karpati MONTRFAL, $P Q$

Patrick L. McGeer VANCOUVER, BC:

William Pryse-Phillips $\$$ L. JOHNS, NF

Ali H. Rajput SASKATOON, SK

Richard J. Riopelle KINGSTON, ON

James 'J. Rutka TORONTO, ON

Richard Stein EDMONTON, AB

John D. Stewarl MONTKLIAL, PQ

Garnette R. Sutherland CALGARY, AB

Jean-Guy Villcmure MONTREAL, PQ

Book Review Editor / Redacteur de critiques de livres

Mary Anne lee CALGAKY, $A B$

News Editor/Rédacteur (nouvelles)

John W, Notris ToRONISO, ON

Managing Editor/Administratrice adjointe

Saliy A. Gregg CALGARY, AB

Pablications Committee/Comité de Rédaction

Frances Booth WINNIPE(;, MB

Donatd Brunct KINGSION, ON

Gary Ferguson I.ONDON, ON

William Pryse-Phillips ST. JOHN's, NF
The official journal of: / Ia Revue officielle de:

The Canadian Neurolugical Society Ia Suciété Canadienne de Neurologie

The Canadian Neumosurgical Saciety

La Société Canadienne de Neurochirurgic

The Canadian Stociety of Clinical Neuroplysiologists La Société Canadienne de Neurophysiologic Clinique

The Canadian Association of Child Neurology

L'Association Canadienne de Neurologie Pédiatrique

The permanent secretariat for the 4 societies and the Canadian Congress of Neurological Sciences is al/ Le secrétarial des 4 associalions et du Congrès Canadien des Sciences Neurokguiques est șitue cn permanence à: $810,906-12$ Avenue S.W., Calgary, AB Canada T2R iK7

The Canadian Jouralal of Neurological Sciences is putplishcil alarterly The annual subscription rale is $\$ 60$ for meinlers; $\$ 70$ for non-onembers in Canalu; $\$ 80$ for USA and ejsewhere. Residents, Intesus, Pre- arud Prosk [Doctoral Studenis $\$ 30$ per alinum (inembers); $\$ 40$ per annum (non-mennbers). Single copies $\$ 18$ eacli plus postatge and lenndliug. All nianuscripls and comnarnitationss shoultat be sent W: Canadtan Joutnal of Neurological Sciences. P.O. Box 4220. Station C, Calgary, AB Canada T2'I SNI. Courier 10: 810, 906 - 124h Avenue S.W., Calgary, AR Canads T2R IK7. Telephone (403) 229-9575; Fux (403) 229-1(661. COPYRIGHTO IOSA WY THE CANADIAN JOURNAL OF NEUROLOGICAL SCIENCE:S INC. No part of this journal ntiy be repcoduced in any form withuut the prior permission of 17e Canadian Joumal of Neurologicul Sciences. Mailed under P'ublications Mail registration nuniber 3307. Postage paisl at Calgary, Alberta. This journal is indexed by Index Medicus, Excentit Metica and Cursent Contents - Chitiont Proctice asd tijte Sciesuces.

Le Ioumal Canadien des Sciences Neurologiques est public Itïnectrielientent.

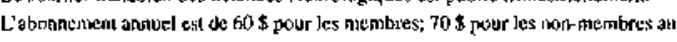

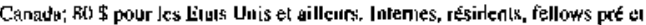

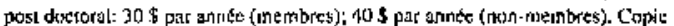
simple: 18.5 plus offiranchisseinent et inarutention. Towtes les communicatious et les mantuscrits dojveat ĉtru adresses à Jevumal Camadien der Sciences Neuroleviques, P.O. Box 4220, Station C. Calgary, AB Cantada T2T SN1. l'ar courtier 810.906 - 121th Avenue S. W., Calyury, AB Canada TZR IK7. Teléphtre (403) 229-9573; Fax (403) 229.1661.

DROITS 1) AUTEURO 1994: THE CANADIAN JOURNAL OF

NEUROI OCICAL \$CIENCES INC. Aucune partie de CC Jersinal ne peul time reproduite. sous quekque ferme que ce soil, șins la l'authorisution du Jobsiral Cararificn des Sciencex Neurologiques. Pozić sous pentris ale poste-publicalion

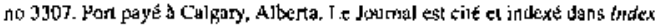
Medicus, Excerpta Medict as Current Contonts - Climical Practice er Lifc Sciences.

Advertising representative/Représentant de publicite: Sally Ciregg, Canadian Joumal of Neurologicil Sciences 810. 906 - 12 Ave. S.W. Calgary. AB Canada T2R $1 \mathrm{~K} 7$ Tel (403) 229.9575 Fax (403) 229-1661

Printer//mprimeur:

McAra Printing Lirnited, 105, 2507 - 12th Street N.E., Calgary, Alberta T2E 7L5

ISSN 0317 - 1671 


\section{A well}

orchestrated

approach

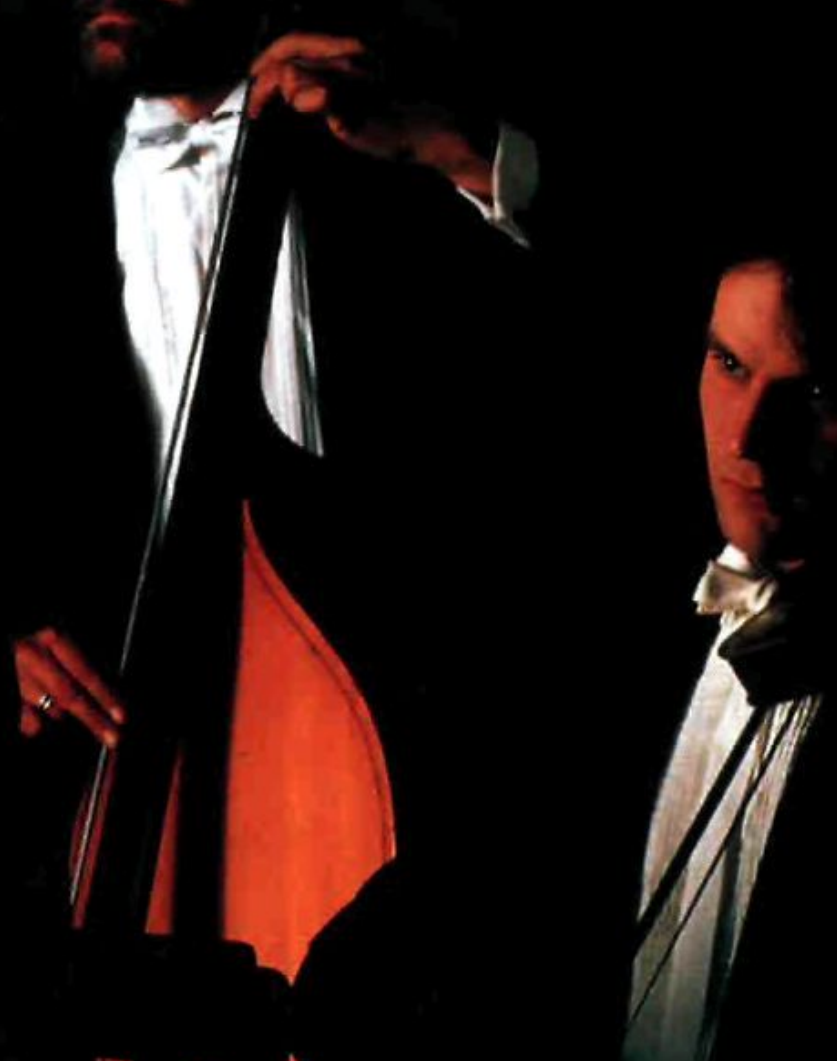

Rational therapy with Frisium is a well orchestrated approach to complete seizure control in patients of all ages, regardless of seizure type. Adverse events with Frisium are generally mild and transient.' Clinically significant drug interactions are uncommon, and impairment of alertness is less pronounced with Frisium than with other benzodiazepines. Help keep these patients in harmony with their surroundings.

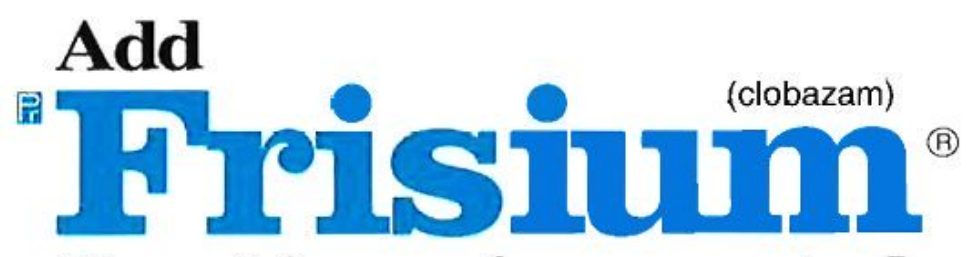

To achieve seizure control. 


\section{INFORMATION FOR AUTHORS}

The Canadian Journal of Neurological Sciences publishes original articles in neurology, neurosurgery and basic neurosciences. Manuscripts are considered for publication with the understanding that they, or the essence of their content, have not been published elsewhere except in abstract form and are not under simultaneous consideration by another journal. Manuscripts should be submitted to:

James A. Sharpe

Editor

Canadian Journal of Neurological Sciences

P.O. Box 4220, Station C

Calgary, AB Canada T2T $5 \mathrm{~N} 1$

\section{Manuscript Preparation}

- Submit five high quality copies of the manuscript. Papers will be accepted in English or French. All papers should be accompanied by an abstract of 150 words or less on a separate page, preferably in both languages, although the Journal will provide the translation if required. Manuscripts must be double spaced throughout including references, tables and legends for illustrations. Margins of at least $25 \mathrm{~mm}$ should be left on all sides.

- After a paper has been reviewed, the author will be requested to submit four copies of the revised manuscript, including illustrations and a computer diskette ( $31 / 2^{\prime \prime}$ or $51 / 4^{\prime \prime}$ size) containing the article. Identify clearly first author's name, file name, word processing program and version, and system (i.e.: DOS or Mac). Clearly indicate the order and importance of headings.

- For detailed instructions regarding style and layout refer to "Uniform requirements for manuscripts submitted to biomedical journals". Copies of this document may be obtained by writing to the Journal office, but the main points are summarized here. Articles should be submitted under conventional headings of introduction, methods and materials, results, discussion, but other headings will be considered if more suitable. Pages of text should be numbered consecutively.

- A title page should identify the title of the article and be no more than 80 characters including spaces, name of institution(s) from which the work originated and the address, telephone, and fax number of the corresponding author.

- Acknowledgements including recognition of financial support should be typed on a separate page at the end of the text.

- The SI system (système international d'unités) should be used in reporting all laboratory data, even if originally reported in another system. Temperatures are reported in degrees celsius. English language text may use either British or American spelling, but should be consistent throughout.

- References should be numbered in the order of their citation in the text. Those cited only in tables and legends for illustrations are numbered according to the sequence established by the first identification in the text of a particular table or illustration. Titles of journals should be abbreviated according to the style used in Index
Medicus. References should list the names of up to five authors; if there are more, cite the first three, then et al. Provide the full title, year of publication, volume number and inclusive pagination for journal articles. For any reference cited as "in press", five copies of the article must accompany the author's manuscript. Do not reference unpublished or "submitted" papers; these can be mentioned in the body of the text and authors must provide five copies of "submitted" manuscripts. Avoid "personal communications" and, if necessary, include them in the body of the text, not among the references. Reference citations should not include unpublished presentations or other non-accessible material. Books or chapter references should also include the place of publication and the name of the publisher. Examples of correct forms of reference follow:

\section{Journals}

Yang JF, Fung M, Edamura R, et al. H-Reflex modulation during walking in spastic paretic subjects. Can J Neurol Sci 1991; 18: 443-452.

Chapter in a book

McGeer PL, McGeer EG. Amino acid neurotransmitters. In: Siegel GJ, Albers RW, Agranoff BW, Katzman R, eds. Basic Neurochemistry. Boston: Little, Brown \& Co., 1981: 233-254.

- Illustrations Submit five original sets of illustrations. We will not return illustrations; therefore, authors should keep negatives for all photographs. Submit high quality glossy black and white photographs preferable $127 \times 173 \mathrm{~mm}\left(5^{\prime \prime} \times 7^{\prime \prime}\right)$. Original artwork and radiographs should not be submitted. The additional cost of coloured illustrations must be borne by the author; quotations are available upon request from the Journal office. Identify each figure with a label at the back indicating top, figure number and first author. Letters and arrows applied to the figures to identify particular findings should he professional appliques suitable for publication. Photomicrographs should include a calibration bar with a scale indicated on the figure or in the legend. Legends for illustrations should be typed on a separate page from the illustrations.

- Tables Type tables double-spaced on pages separate from the text. Provide a table number and title for each. Particular care should be taken in the preparation of tables to ensure that the data are presented clearly and concisely. Each column should have a short or abbreviated heading. Place explanatory matter in footnotes, not in the heading. Do not submit tables as photographs.

- Review articles on selected topics are also published. They are usually invited, but unsolicited reviews will be considered. It is recommended that authors intending to submit review articles contact the Editor in advance.

- Letters to the Editor concerning matters arising in recent articles are welcome. Letters should be limited to two double-spaced pages and may include one illustration and a maximum of four references.

- Permissions and Releases Any non-original material (quotations, tables, figures) must be accompanied by written permission from the author and the copyright owner to reproduce the material in the Journal. Photographs of recognizable persons must be accompanied by a signed release from the legal guardian or patient authorizing publication. 

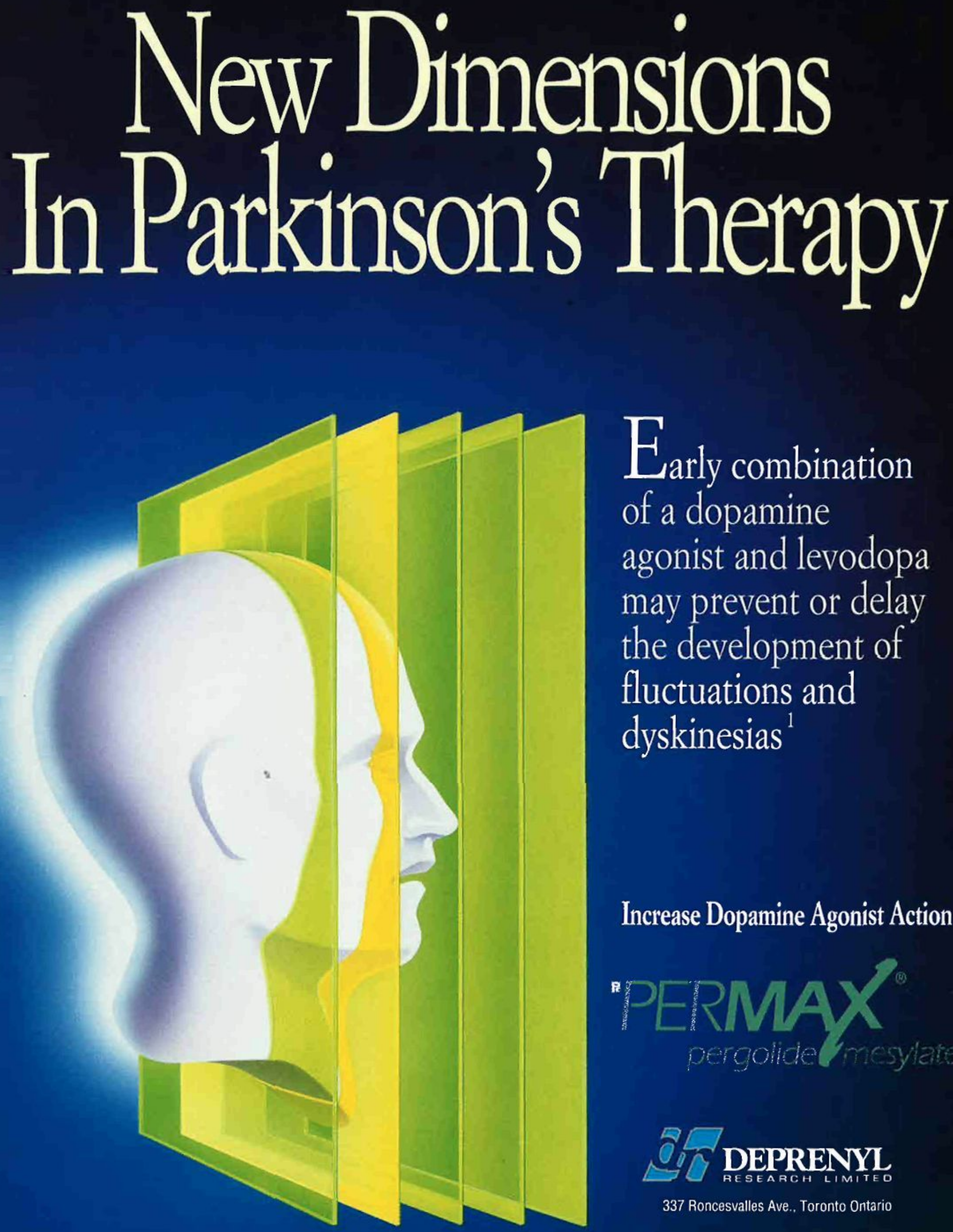

Early combination of a dopamine agonist and levodopa may prevent or delay the development of fluctuations and dyskinesias $^{1}$

Increase Dopamine Agonist Action

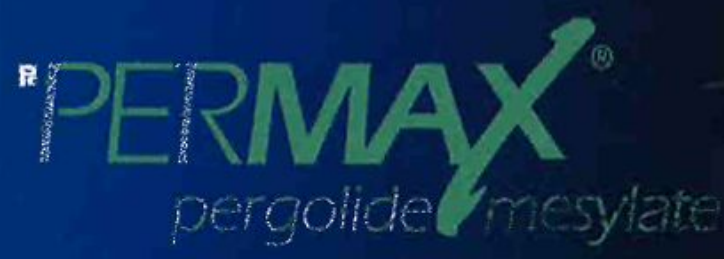

\section{OCG DEPRENYL}

337 Roncesvalles Ave., Toronto Ontario 


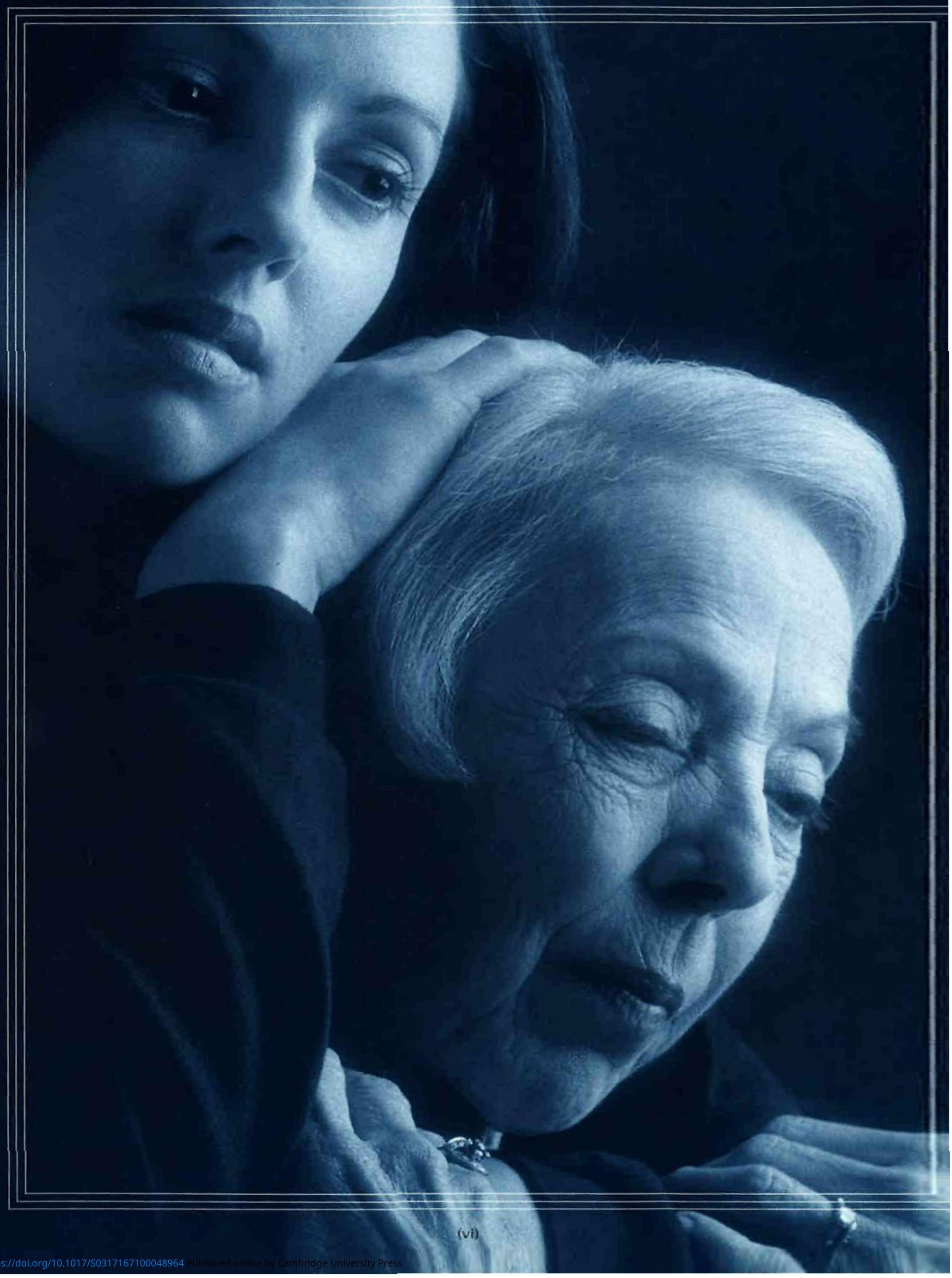




\section{You may have \\ only days to prevent her stroke.}

\section{) \\ Which therapy do you choose?}

$\mathrm{n}$ the prevention of stroke,
early intervention is crucial. The risk of initial stroke is greatest in the year following a TIA, with the highest incidence occurring in the first month. And the risk of recurrent stroke increases fivefold after a first stroke. ${ }^{2}$

In major clinical trials, Ticlid has been shown to be the most effective therapy for the prevention of non-cardiogenic thromboembolic stroke. ${ }^{3,4}$ In the first year after a TIA, Ticlid reduced the risk of stroke $47.6 \%$ more than $\mathrm{ASA}_{\text {, }}^{5}$ and particularly benefited certain patient subgroups. ${ }^{67}$

Ticlid has also been proven to reduce the risk of recurrent stroke by almost half compared to ASA:

To date, Ticlid remains the only therapy indicated for and proven effective in the prevention of both initial and recurrent stroke in men and women. 910

Side effects with Ticlid have been shown to be manageable, transient

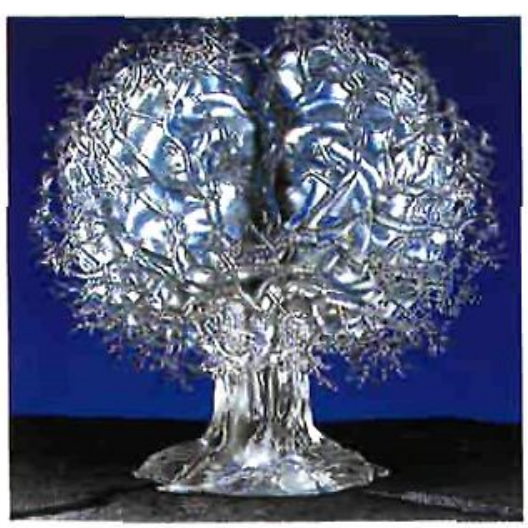

EFFICACY AND RISK REDUCTION IN PATIENT SUB-GROUPS ${ }^{6.7}$

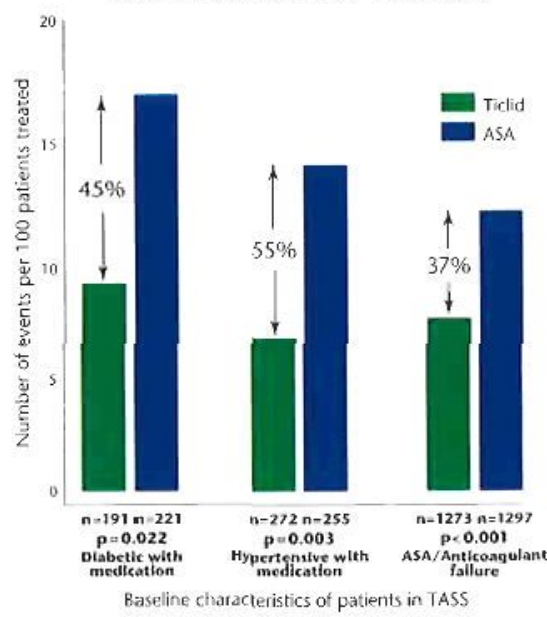

and to occur early in therapy. ${ }^{10}$

In clinical trials, there was a $2.4 \%$ incidence of neutropenia ( $0.8 \%$ severe). Upon immediate discontinuation of therapy, the neutrophil count usually returned to normal within one to three weeks. ${ }^{10}$ Managing the condition requires $W B C$ monitoring every two weeks for the first three months of treatment, starting at baseline. ${ }^{10}$

From the moment your TIA or stroke patient is at risk, consider Ticlid.

Dosage: $250 \mathrm{mg}$ BID with meals

"Ticlopidine Aspirin Stroke Study, subgroup of patients with completed minor stroke.

\section{Ticlidi \\ ticiopidine hydrochloride $250 \mathrm{mg}$ tablets}

Nothing protects patients from stroke more effectively. 


\section{Ticlids}

TICLID (tidopidne hydrochloride) $250 \mathrm{mg}$ Tablets

THERAPEUTC CLASSIFICATION Inhibitor of Platele: Function

ACTION Ticlid (ticlopidine hydtochloride) î an inhibitor of platelet aggregation, it causes a time and dose dependen?

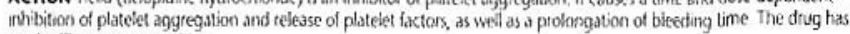
no sigrificant in witro activity.

The exact mechanism of action is not fully characterized, but does not involve inhibition of the prostacycingthromboxane pathways of plastet c CAMP.

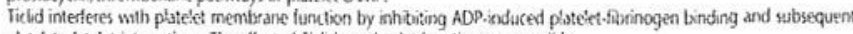
phateles-platelet interoxtions. The eflex of ficlid on platelet function is iteversible.

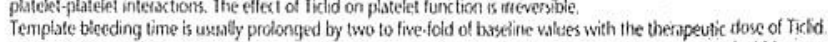

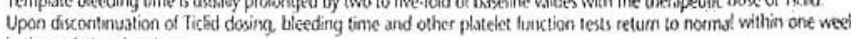
in the majority of patients.

The correlation between ticlopidine hydroxhlorde plasnn levels and actinty is stit undey imestigation, Much of the following data was obtained from oldes putients corresponding to the age of patients partikipating in dinicat trials (mean age: 63 years)

a ther oral admenstration of the therapeutic dose of Ticid, rapid absorption oxcurs, with pesk płasna fevels occurning a increased (20\%) lesel of ticiopidne hydrochloride in plssma.

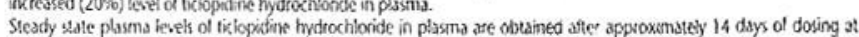

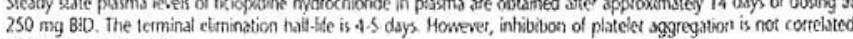
$250 \mathrm{mg}$ BiD. The termina
with plauma ding levels.

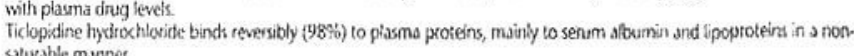

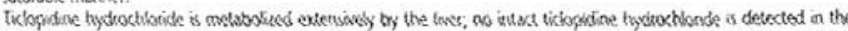
urine Uneneiabobzed ticlopidine hydrochloride is a minor component in plasmo sitter a single dose, bat at teeady state ticlopidine hydrochioride is the mior combonent.

Impaised hepatic function resulted in highes than normal plasna levels of unchanged ticlopidine hydrochlonide after single doses or attet multiple doser.

Inhibition of plotelet oggregation is detected withun 2 days of stminstrotion with $250 \mathrm{mg}$ BID. Maximum platele aggregation irhibition 6 achew

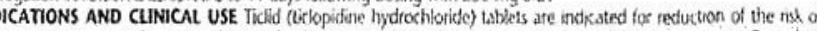
tirst of tecurtent stroke tor putients who have expesienced at lesst one of the following events; Complete

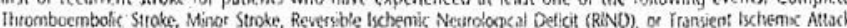
(TM) inciuding Transient Moriouviar Bindness (TMB).

Consderations in the se'exton of trobe prevention therapy shouid unchude the patient's cument medical slatus and history, and their abifty to compiy with the required blood manitoring instructions conkerning the use of ticlopidine

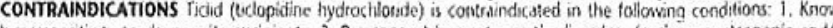

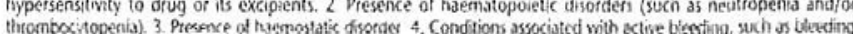

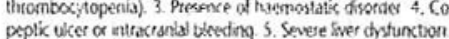

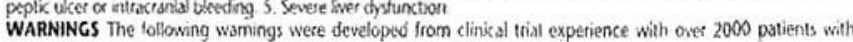
WARNINCS The following wamings were developto from clinical trial expenien

Neutropenia and Thrombocytopenia: About $2.4 \%$ in of tichopidine treated paticents in chnical trials developed Neutropenia and Thrombocytopenia: About $2.4 \%$ of tichoidine,trested piticents in (banical tials developed

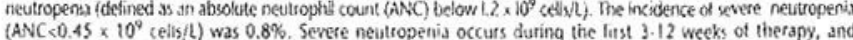
(ANC $<0.45 \times 10^{\circ}$ (ellis $L$ ) was $0.8 \%$. Severe neistropenia occurs during the litst 3.12 weeks of therapy, and
may develop quickly over a lew days. The bone marrow shows a reduction in myeloid precursors. may develop quickly over a lew days. The bone marrow shows a reduction in mycloid ptecursors
The condition may be life-threatening. It is usualiy teversible, and the recovery occurs within 1.3 weeks atter The condition may be life-threstering. It is usualiy tevet

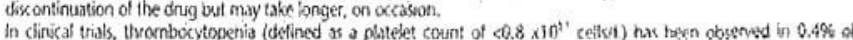

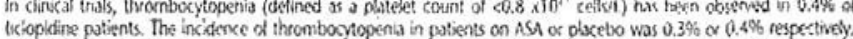
liciopdine patients. The incidence of thrombocytopenta in putients on ASh or placebo was $0.3 \%$ o $0.4 \%$ respectively.

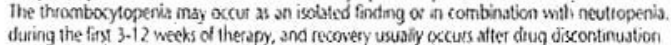

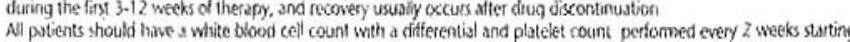

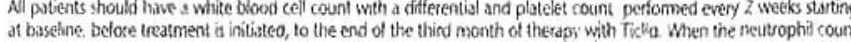

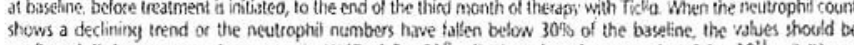
confirmed. If the presence of nevtropenta (ANC $<1.2 \times 10^{9}$ cetistl) of thrombochtopenia $\left(<0.8 \times 10^{11}\right.$ cells/t), at

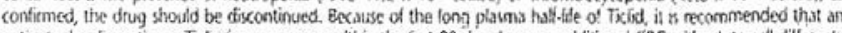

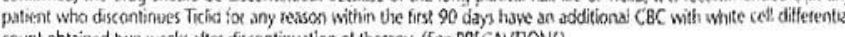
count obtained two weeks alter discontinustion of therapy, (5re PRECAUnONS)

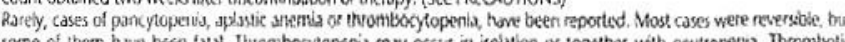
some of them have been fast. Thtombocytopenia may oxcut is isolation or together with neutsopenta. Thrombot: thrombocylopenic purpura (TiP) has been reponted, therefore carehis attention to dagnosis should be made to guide Itcatment, platesc tuanfusion mary be harmlu' on these patsent

Hemorrhagic Complications: frolongation of blecding time occurs in subyeds treatted with Tichid purpurs and a few cases of more serious hemorthogic events such as hematemesis, melena, temothorax and intracranial beeding hive bet reponted. Patients must be instruxted to wateh for signs of bleeding disorders and to repon any atnormality to the

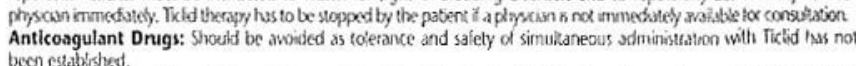
beor estathishised.

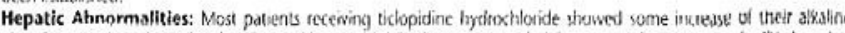

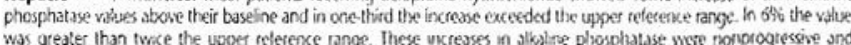

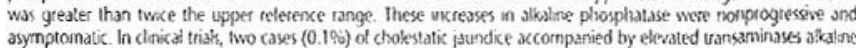

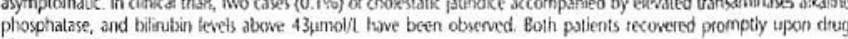
discontinuation

Pregnancy: The satety of Thiad in pregnarcy has not been establshed. It should not be used a pregnant patients

Pediatric Use: Salety in chidden las not been studíd. Do not we in pediatric patients.

PRECAUTIONS

Selectlon of Patients: Tklid shovid be used onty loc the established andications (cee INDiCATIONS) and should not be

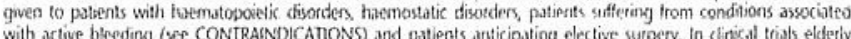
with active bleeding (ser CONTRANOICAMONS) and patients anticipating elective surgery, In clinical trials elderly patients tolerated the dingy well, but sutety in children and pregnant women have not been extabssthed.

Clinical Monitoring: Ail patients have to be carefully monitored lo clincical tigns and symptorns of adverse drug texctions (see ADVERSE REACCTIONS). The signs and symptorns possibly related to neutropenis (tever, thills, sore throat, ukecations in oral cavity), thrombocytopenia and abnormal hemostassis (prolonged of unuswal boceding. bruising.

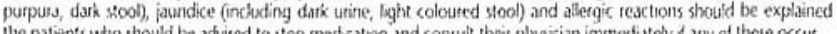
the patients who should be advised to stop medzation and consult thes plyzixian immediutely 4 any of these occut Laboratory Monitoring: Al putients should huve a white blood cell count with a differentid and a platelet count performed excy 2 weeves stanting at basefine, befoce trestment is inituted, to the end of the third month of therapy with Ticlid. When the neutroghil count shows a declening tend of the neutrophial nambers have fallen below 30 ofs of the

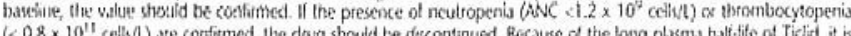

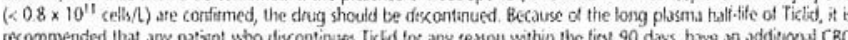

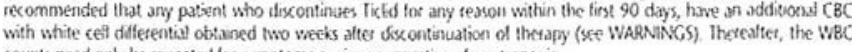

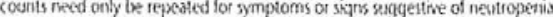

Elective Surgery: Ficlid should be discontanued 10 to 14 days prot to elective surgery or dentat extraction and blecting lime and thrombecyte couth perfotmed before the procedute it cinically indicated

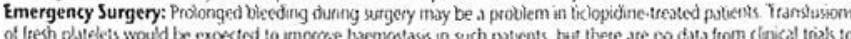
conflun thes expectation. There ate dats from clinical pharmatology these ate no dats from clancal inats to

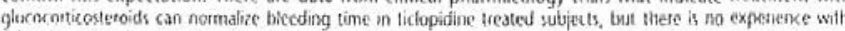
ticlopidate-treated surgkal patients to show that such treatment improses hutmostasis.
Spectfic Precautions: Live: Trcid is contrandicated in patients with severe Irves dystunction or cholestatic jaundice majority of patients (see WARNINGS and CONTRAINDICATIONS)

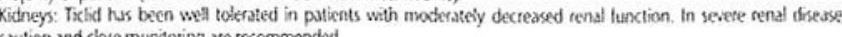
caution and close menviloting are recommended.

Gastrointestinal System: Condtions associated with ox tive blexding, such as bleedirg whers, construte contrandication lor Fichd. Cinical iudgament and monitoring of slool for oxcult blood ate required lor putients with a history of ukerative

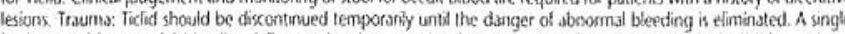
fatal case of intracranial bleeding folowing hesd trauma has been reported. The extent to which Ticlid may hawe contributed to the severity of the bleeding is unknom.

Drug Interactions: The following table outlines the agents which have been concomitantly sdainistered with ticlopidine

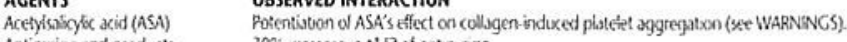

Antipyrine and products

metabotized by hepatic

3030 increase in $11 / 2$ of antipynine

Dose of products metabolired by heppatic mictosomal enyymes to be adparted

when slating os stopping concomitant therapy with ticlopidine hydrochibride

11/2 of theophlyline incressed from 8.6 :0 $12.2 \mathrm{hr}$ along with a comparable reduction in is total phisma clearance.

Digoxn Approximstely 15\% reduction in digoxin plasma levels, (Iittle or no change in

Cimetidine $\quad$ Chigonic admoticksitation of cimetedine induced a $50 \%$ reduction in clearance of a

Antacids sing/e dose of ticlopicine hydrochloride.

Phenoburbital No interscion reported

Other Concomitant Therapy: Akhough sperofic interacton studes were not pertomed, in clinical studies, IICL 10 was

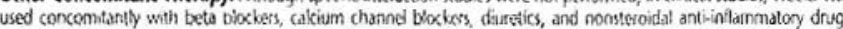
(trowever see WNENNING5) without evidence of clinically signifiant adverse interactions.

ADVERSE REACTIONS Most adverste effects are mild, transiont and occur easily in the course of treatment.

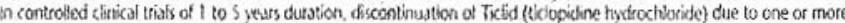
adverse eflects was required in $20.9 \%$ of patients. In these same trist. ASA and placebo led to dixcontinuation in $145 \%$ and $6.7 \%$ of patients respectively. The uncidence sates of adverse reactions listed in the following table were derived trom

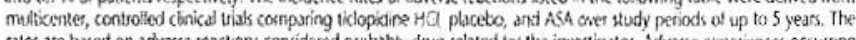

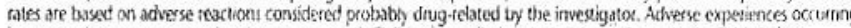
in greater than ore percent of pattients sreated with Ticlio in controlled clankal trials ate shown in the Table below.

PERCENT OF PATIENTS IN CONTROLLED STUDIES

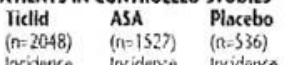

Event

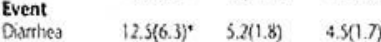

$\begin{array}{llll}\text { Oadrthea } & 12.5(6.3)^{*} & 5.2(1.8) & 4.5(1.7 \\ \text { Dospepris } & 7.0(1.1) & 9.0(2.0) & 0.9(0.2)\end{array}$

$\begin{array}{llll}\text { Grpespos } & 7.01 .17) & 9.0(2.0) & 0.9(0.2) \\ \text { Gipain } & 3.7(1.9) & 5.642 .7) & 1.30 .4)\end{array}$

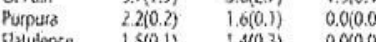

$\begin{array}{llll}\text { Platumine } & 1.5(0.1) & 1.4(0.3) & 0.0(0.0) \\ \text { Dizzness } & 11(0.4) & 0.5(0.4) & 0.0 \times 0.0)\end{array}$

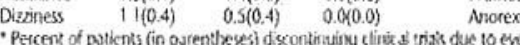

Tketid ASA Placebo

$(n=536)$

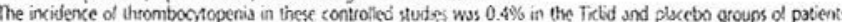
and $0.3 \%$ in the ASA pationt popstation

The following sare extents have been repoted and the: relationship to Tichin is unkertain

Pancylopenia, hemolytic anemia with teliculocviosis, litromobcytopenic thrombotic purpura, jaundice, allergit pneumocitis, systemic lupus (positime ANA), periphena neuroputhy, vascalitis, serum sickress, arthropathy, hepatitis

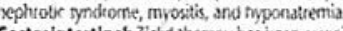

Gastrointestinat: Tkldd therapy has betr. asscxiated with a yariety of gastrointestinal complains induding daarthes and nasues. The inijority of cases are midd and transient in nature and oxcur within 3 months of iritiation of therapy Typically, events se resolved within 1.2 weets whthout discontinuation of therapy. It the effect is severe or patsistent therapy ghould be discontion

Hemorrhagic: Tkidid has been associated with a numbes of blceding compsications such ss ecchymosis, epistacin hernatuna conjurctival hemortiuge gassointestinal bleeding and postoperatw bbeding.

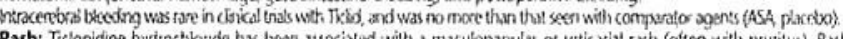

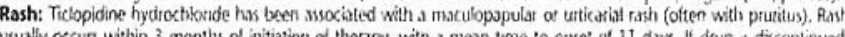

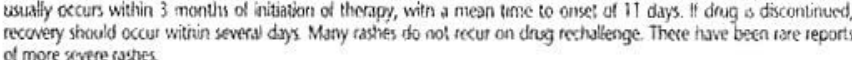

Aftered Laboratory Findings: Hematological' Neutropents and rately thombocylopenia have been associated with Altered Laboratory Findings: Kiem
Yictid adminissation (see WARNINCS)

Liver: Ticio therapy has been associated with devations of albaline phosphutase (See WAGivinC,5). Maximal dhange

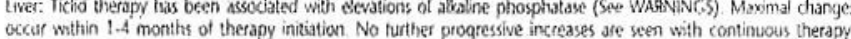
Occasonsty patients devoloped deviatons in isitubior ard SGOT.

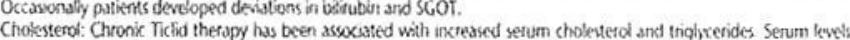

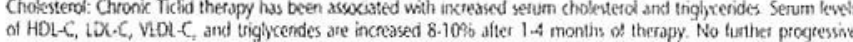

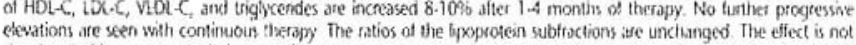
corretaled with age, sex, aloohol use, or dinteres

SYMPTOMS AND TREATMENT OF OVERDOSACE One case of delibcrate overdosage with Iiched (tictopidine

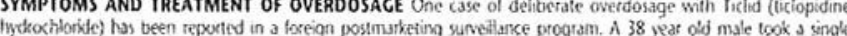

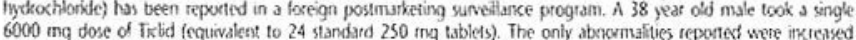

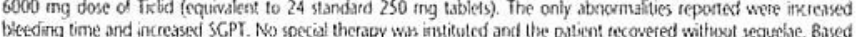

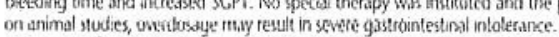

In the case of excessive bloeding after injury or surgaty, itandard supportive measures should be carned out findicated,

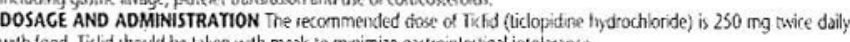
Whth ford. Ticlid should be taken with meals to mnimize gastroinlestinal intolerance.

PHARMACEUTICAL INFORMATION

(1) Drug Substance

Description: TK. Gopidine hydrochlonde is a white crystatine solid it is freely soluble in water and sell butfers to a pH 0

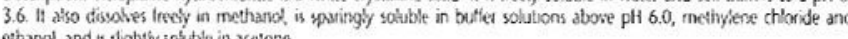
ctharnol, and is thighthy solutise in scetone.

(ii) Compostion. Ticlopidine hydrechlonide iables are provided, as white film toated esbless containing tiktopidine

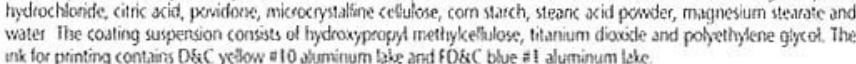

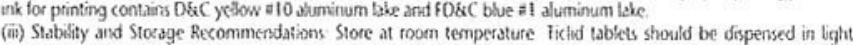
resistant containers. Bister packs shoukt nol be exposed to tight

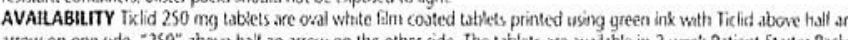

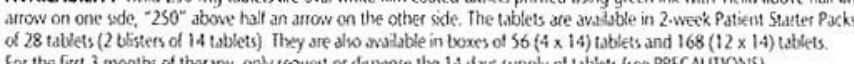
for the first 3 months of thesasy, only request or despense lle 14 diays supply of tablets (ree PRECAUNONS)

Product Manoxpaph avalable to Health Protessionals on request

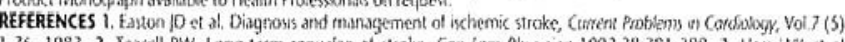
1.76, 1983 2. Teusell RW. Long-term sequafae of stoke Can fam Physkian 1992;38:381-388. 3. Hass WK et at Iixlopidine Aspirin Strcke Study (TASS). A randonvized trial compusing liclopidine hydrochlocide with sspitin for the prevention of stroke in high-ink patients $N$ Engl / Med 1989;321:501.7. 4. Gent M et at. The Canscisn Anerican

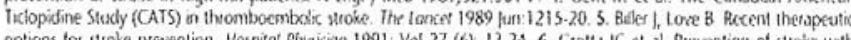

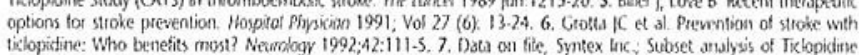

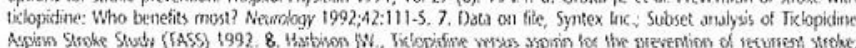

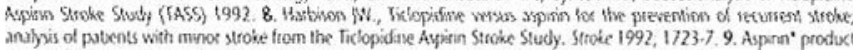
monogtapht, ("Asprin is a regstered trademark of Stering Drug L Itd) 10. Ticled product mosiograph.

S SYNTEX (6yntex Inc. Mississauga, Ont./Montréal (Qué.)

\begin{tabular}{|l|l|l|l}
\hline PAAB & muBen \\
CCPP & PMAC \\
\hline
\end{tabular} 


\section{NOW ELDEPRYL IS INDICATED FOR FIRST LINE THERAPY.}

Now you can do more than deal with the disability of Parkinson's disease. You can delay it with Eldepryl first line. $\square$ In newly diagnosed patients, Eldepryl can significantly retard the worsening of symptoms ${ }^{2,3}$ and delay the need for levodopa therapy., ${ }^{2,5} \square$ In fact, Eldepryl can delay the onset of disability and thereby prolong functional life by as much

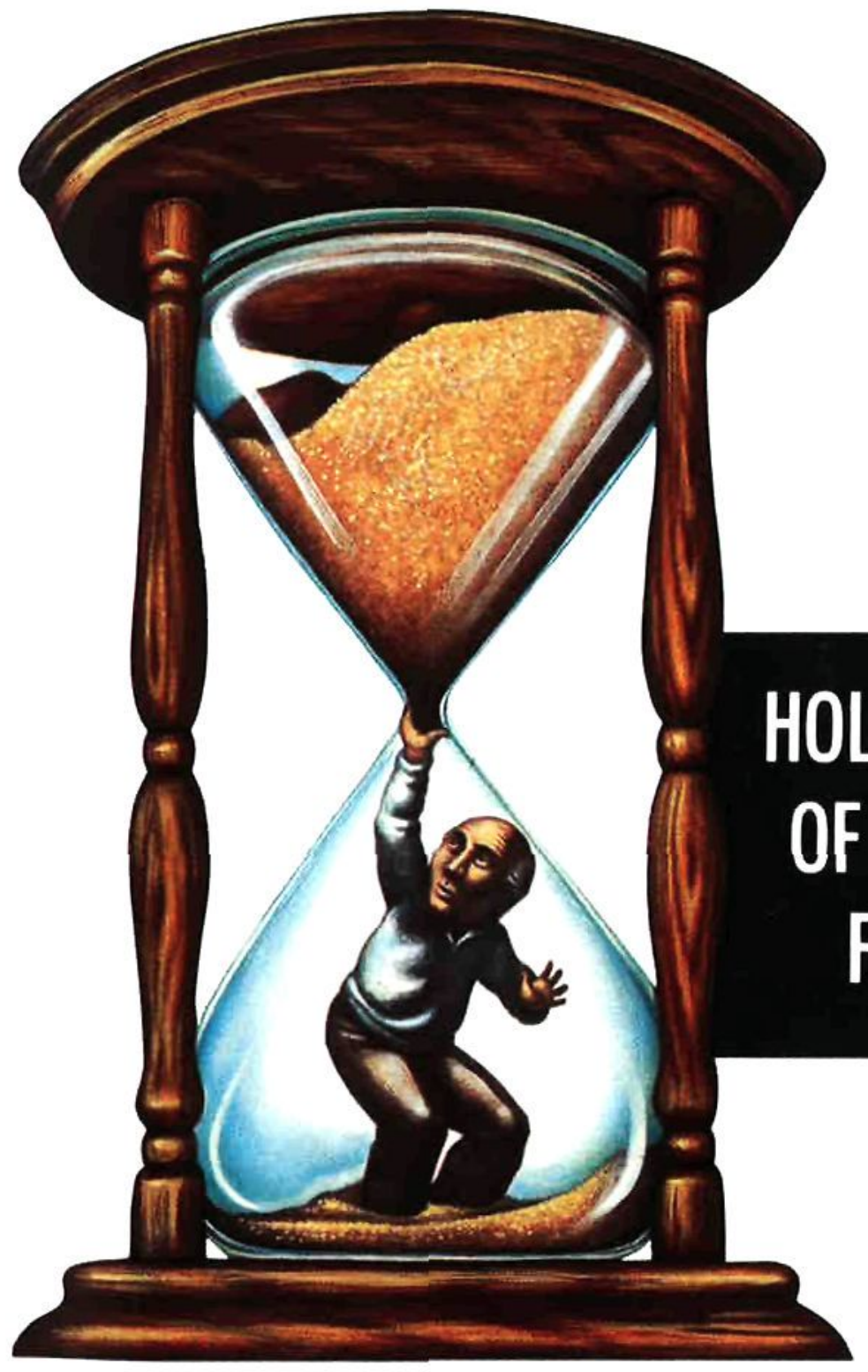
as one year., ${ }^{1,4} \square$ As well, Eldepryl appears to have a remarkable safety profile. It has been generally welltolerated with few side effects. ${ }^{4,6,7}$

$\square$ So when you see patients with Parkinson's disease, prescribe Eldepryl first line. It's their first line of defence against the progression of disability.

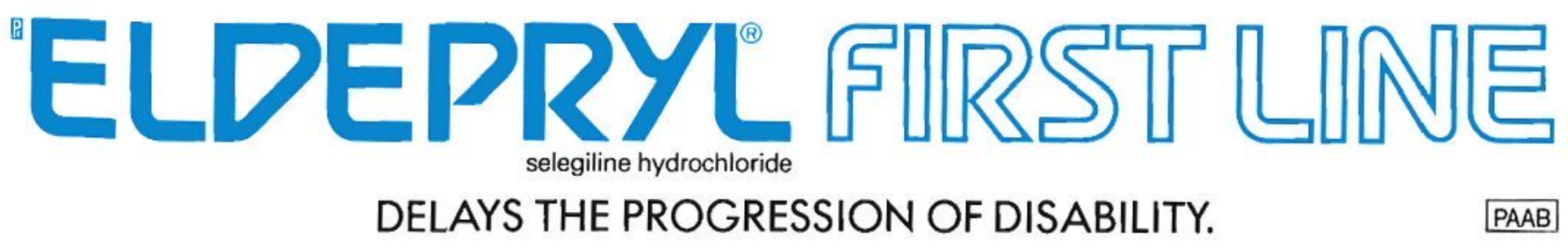




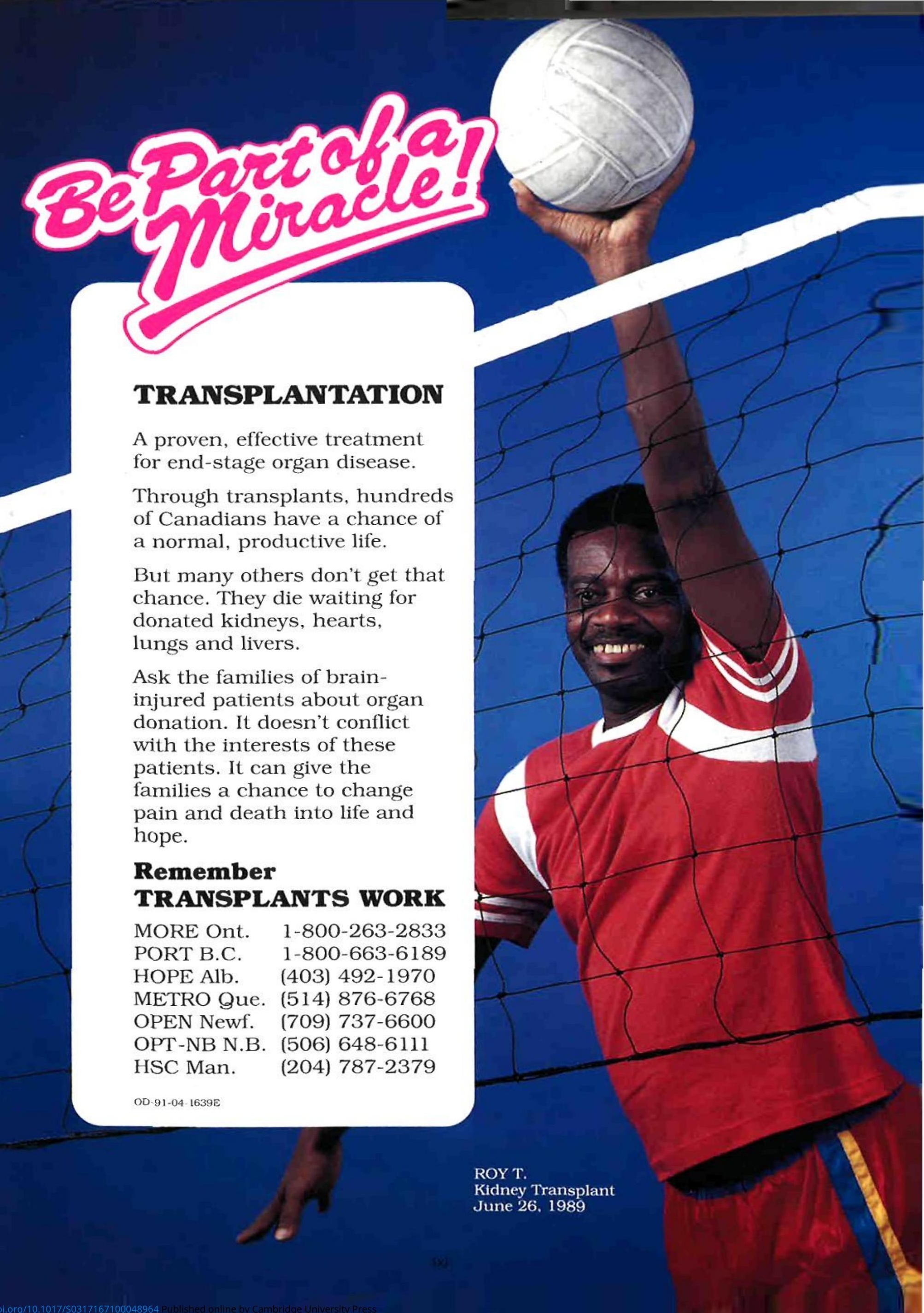




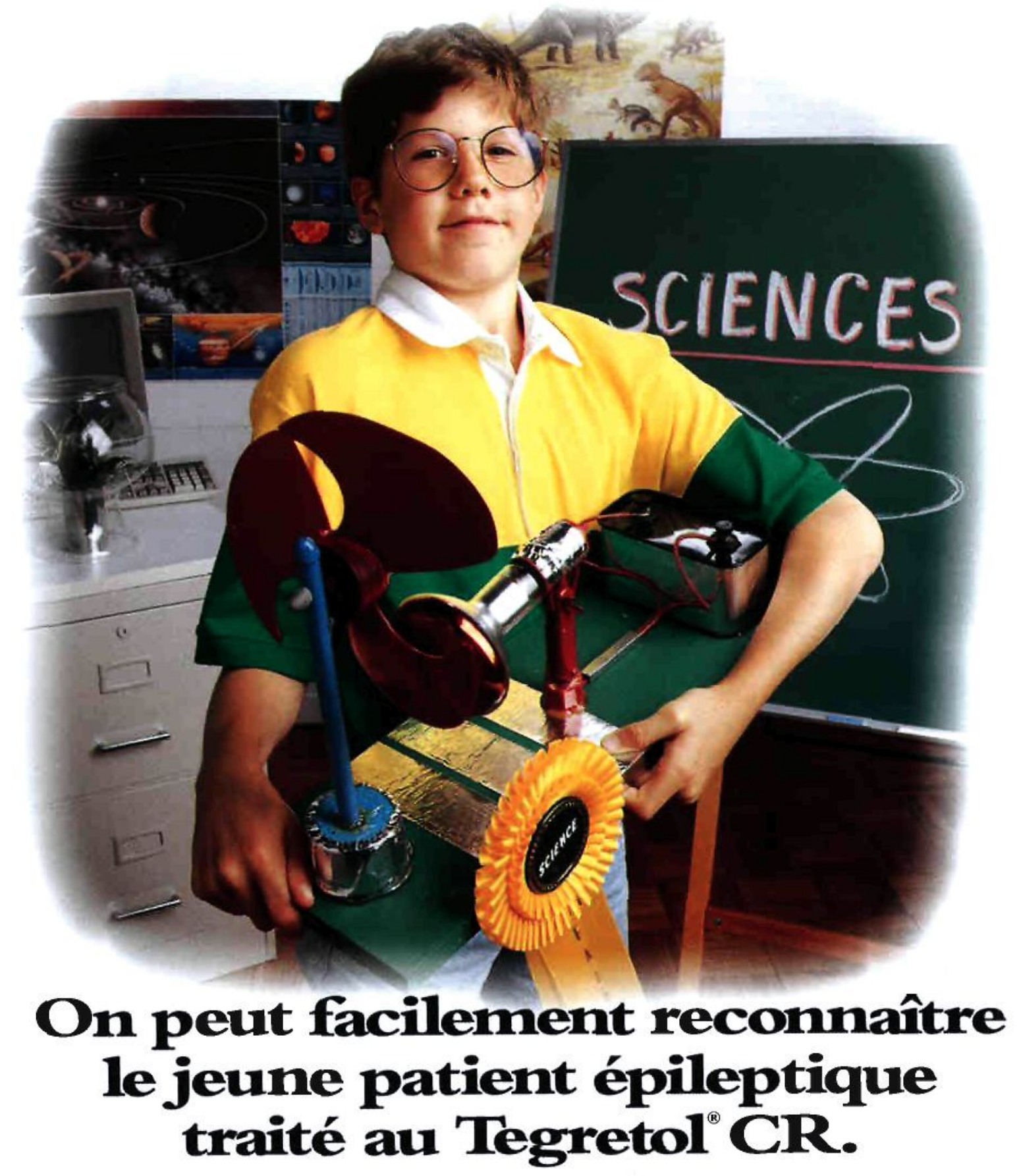

Excellent contrôle des crises

圆 Tegretol ${ }^{\star}$ CR (carbamazépine à libération contrôlée) maitrise les crises chez de nombreux patients, causant peu d'impact sur la fonction cognitive ${ }^{1.2}$. Tegretol CR permet à de nombreux patients de penser clairement et de donner le meilleur d'eux-mêmes ${ }^{1,2}$.

\section{Taux sanguins uniformes}

Tegretol CR cause moins de "hauts et de bas» dans les taux sanguins que le Tegretol conventionnel. Les effets secondaires sont ainsi réduits et le modèle de fonction cognitive est plus stable $e^{3,4}$.

\begin{tabular}{ll}
\hline PAAB \\
CCPP
\end{tabular}

\section{Posologie b.i.d. commode}

Lorsque vous instituez ou remplacez un traitement, pensez au Tegretol CR. Il est présenté en comprimés à $200 \mathrm{mg}$ et $400 \mathrm{mg}$ facilement divisibles pour une plus grande souplesse d'administration et améliorer

l'observance du patięnt.

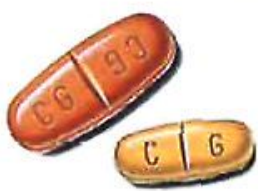

\section{TEGRETOL CR.} Aide les épileptiques à réaliser leur plein potentiel.

\section{Geigy Dorval, Qué. H9S 181}




\section{Epival}

THERAPEUTIC CLASSIFICAYION An:ICORVUISARL

INDICATIONS AND CLINICAL USE Sole or adjunctive therap in the ireatment of simple or complex absencé seizures including petut ma! useful in primaty generalized seizures wi tonic clonic manifestations. May also be used adjunctively in patients with multiple setzure types which include etther absence or tonic-cionic seizures

In accordance with the international Ciassitication of Serzures simple absence is defined as a very briet clouding of the sensorium ot los5 of consciousness (lasting usually 2.15 seconds) accompanied by certarn generainzed epileptic discharges withoul other detectable clinical signs Complex absence is the term used when other signs are also presen CONTRAINDICAIIONS Should not be administered to patients with hepasic disease of significant dystuncticn. Contraind ated in patients with known hyper sensitivity :o tne drug WARNINGS Hepatic faliutes resuliting in fatalities have occurred in patuents receiving valptoic acid and its deriva tives These incidences usually have occurred during the firs six months of treatment with valptoic acid A recent survey study of valproate use in the United States in nearly 400,00 patients between 1978 and 1984 , has shown that children under two years of age who received the drug as part of multupte anticonvulsant therapy were at greatest risk (nearly 20.foid increase) of dereloging fatal hepatotoxtrity Thes patients typically had other medical conditions such as conaerual metabolic disorders mental retardation or organic brain disease in addition to severe seizure disorders The ris in this age group decieased considerably in patients receiving valptoate as monotherapy Simularly patients aged 3 to io years were at somewhat greater risk if they received multiple anticonvulsants than those who recesved only vaiproate fisk generally declined with increasing age No deaths have been reported in pattents ovet 10 years of age who received vaproatc alone

II Epival is to be used in chuldren two years old or younget. t should be used with extreme caution and as a sole agent the benefits of seizure control should be weighed against the risk Serious of tatal hepatotoxicity may be preceded by non specific symptoms such as loss of seizure control. maiaise weakness, lethargy. anorexia, and vomiting Patients and parents should be instructed to report such symptoms Because of the non-specilic nature of some of the early signs. hepatotoxicity should be suspected in patients who become unwell o the rnan through obvious cause, while laking Epiva (divalproex sodium)

Liver function rests should be performed prio: to therapy and at trequent inter vais thereat ter especially duning the firs 6 months Howevet, physicrans should not rely totally on se. rum brochemisiry since these tests may not be abnormal in all instances, but should also consider the results of carelu interim medical history and physical examination Caution should be observed in patients with a prior history of hepatic disease Patients with various unusual congenital disorders celardation and licse witn proganc brain disease may be at oâricular risk

In high-fisk pat cents, it might also be useful to moniter serum i t trogenen and a bu $\mathrm{m} n$ tor decrease in concentrations and serum ammoria 'o increases in corcentration. f changes occe:, the diug should be discontinued Dosage snould te turated to ard na nta nec at the lowest jose cor sistert with optimal seivure controt

The drug should be discontinued immmediately in the presence of significant hepatic dystunction. suspected oapparent. In some cases, hepatic dystunction has progressed in spite of discontinuation of the drug I the Irequency o adverse eflects, parlicular y elevated liver enzymes, may increase w th increas ig cose therefore, the oenetit gained by improvec se zure con: we ghed against the increased incicence of adverse eflects somelimes seen at higher dosages

Use in Pregnancy: According to recent reports in the medica in Pregnacy: Accoding to rece teratocenicity the alsp ing of woten recerving the cug durirg pregrancy increased in mothers receiving valptoic acio duting the firs trimester of pregnancy Based upon a single repont, it was estumated oregnancy based un a singie repont, it was chidren with spin a bitu 15 approxumely $12 \%$ This risk simular to that which apples to non epoptic wom This risk had childen with ueurat itbe detects (anencephaly and spe butida) Anmal studies have demonstiated aly and spina induced teratogenicity. and studies in human females have cemonstrated placental transler of the drug

Mutiole reports in transler of the drug

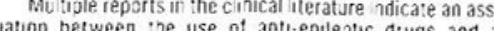
increased incidence of burth defects in chidren oon to

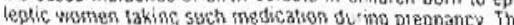
incidence of congerital malformations in the general pepta

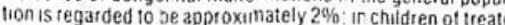
epilep:Ic womer, this rcidence Tay be ircreased $2 \cdot 0$. 3 -to d malformations of the heart clett lip or palate, and congerit detects Neyertheless, the great maiprity ot mothers recerv anti-eptientic medications deliver normal intants
Data are more extersive with respect 100 oheny hycar loin and phenobarbital but these druos ate also the most commonly prescribed anti-epueptics Some reports indicate possible similar association with the use of other anti-epileptic drugs, including trimethadione, paramethadione. and val. proic acid However, the possibility also exists that othe lactors, e g genetic predisposition or the epileptic condition itself may contribute to or may be mainly responsible for the higher incidence of birth detects

Anti-epileptic drugs should not be discontinued in patients to whom the drug is adminustered to prevent maio seizures because of the strong possibitity of precipitaling alus eptepticus with atendant hypoxia and risks to both the mother and the unborn child With regard to drugs given tor minor seizures, the risks of discontinuing medication prior to of during pregnancy should be werghed against the risk of conte iar family history

Epileptic women of child.beating age should be encour oed to seek the counsel of their physician and shouid report the onset of pregnancy promptiy to him Where the necessity tor contrnued use of anti-epileptic medication is in doubi. aporoprate consu :alıon is irdicaled

Nursing Molhers: Valproic acid is excreted in breast 1 to thould of serum concentrations As a general rule, nursing divalproex sodium

Ferlilily: Chronic toxicity studies in juvente and adull tals and dogs demonstrated reduced spermatogenesis and testicular atrophy at doses of valproic acid greater than $200 \mathrm{mg} / \mathrm{kg} /$ day in rals and $90 \mathrm{mg} / \mathrm{kg} /$ day in dogs. Segment crthity studies in rats have shown that doses up to $350 \mathrm{mg} / \mathrm{kg}$ f day fot 60 days have no effect on ferthity the effect of divalproex sodium and valproic acid on the development of the testes and on sperm production and fertlity in humans is LONG.TEAM TOXICITY STJDES N GA'S AVD MCE INOICATED A POIEN TIA CARCINOGENIC RIS

PRECAUTIONS Hepatic dystunction. See CONTRAalvidiCAIICVS and WARNINGS

General: Because of reports of thrombocytopenta and inhibition of platelet aggregation, plateter counts and uleeding. time determination are recommended betore instituting ther apy and at periodic intervals it is recommended that pattents be monitored for platelet count prior to planned surgety Clinical evidence of hemorrhage. brasing or a disorder of hemostasis/coagulation is an indication for reduction of dos. age of withdrawal at therapy pending investipation

Hyperammosemta with or without lethargy or coma has been reported and may be present in the absence of abnormal liver function tests. if elevation occurs the drug should be discontinued

Because Epival (divalproex sodium) may interact with other anti-epileptic drugs, petiodic serum level determina twons of concurtently adminustered anti-epileptics are recommended during the early part of therapy (See DRUG INTERAC. TIONS) There have been reports of breakthrough seizure occurting with the combination of vaiproic acid and phenytoin Epival (divaiproex sodium) is partially eliminated in the urine as a ketone-containing metabolite which

aise interetation of the unice ketore test.

There rave been reports of a lered thyroid function tests is unkrow

Qciving and Hazardous Occupations: May produce CNS epression, especially when combined with another CNS depressant. such as alcohol Theretore, pattents should be acivised not to enģage in hazardous occupations. such as criving a car or operating dangerous machinery. unfil it is known that they do not become drowsy trom the drug

Drug Interactions: May pclentiale the CNS depressan: action of a'cohol

There is evidence that vaiproic acid may cause an increase in serum phenobarbital levels, by imparment of non-rena clearance This phenomenon can resulf in severe CNS depres sion. The combination of valproic acid and phenobarbital has also been reported to produce CNS depression without significant elevations of barbiturate or valptoic acid serum
levels. Patients receiving concomitant barbiturate therapy levels. Patients receiving concomitant barbiturate therapy barbiturate drug leveis shousd be obtained, if possible, and the barbitutate drug levels shousd be obiained,

Primicone is mecased fore, may aiso be involved in a similar or identical interaction There is conflicting evidence regarding the interaction of valproic acid with phenytoin (See PRECAUTIONS - General) It is not known there is a change in serum levels. The dosage of phenytoin should be adjusted as recured by the cl nical sit: $L$ al or

hecorcorritant use of valproic acic and conazepam may produce absence status

ADVERSE REACTIONS The most commonly teported adverse reactions are nausea, vorming dind indigestion sunce valproic acid has usually been used with other anti-epileptics, it is not possible in most cases to determine whether the adverse
reactions mentioned in this section ate due to valpros acid alore or to the combiration of $\mathrm{C}^{\prime} \mathrm{Lg}$

Gastrointestinat: Nausea vomiting and indigestion are the most commoniy reported side effects at the intiation of therapy. These effects are usually transient and rarely require
discontinuation of therapy. Diarthea, abdominal cramps and constipat on have also been reported Arorexia with some weight oss anc increasec appelite wit 7 some weight gain nave (a)en

CNS Ellecls: Sedative etfects have been noted in patients receiving valproic acid alone but are found most often in patients on combination therapy Sedation usually disappeats upon reduction of other antrepileptic medication Ataxia, headactie. nystagmus. diplopia. asterixis. "spots betore the eyes", tremor, dysarthria, dizziness, and incoordination have parely been noted. Rare cases of coma have been reported in pattents receiving valproic acid alone or in conjunction with

Dermatologic: Tansient increases in natr loss have been observed. Skın rash anc petechiae five rarely oeer roted. Endocrine: There have been reports a irregular menses and secondaty amenorthea in patients receiving valproic acic. Abnormal thyroid function tes:s have been reported (See PRECAUTIONS

Psychiatric: Emotional upset cepress on psychosis, aggression, hyperact vity and oehavioural deter oration have

Musculosketelal: Weakness nas beer reporled

Hematopoielic: Thrombocytopena has been reported Valproic acid inhibits the second phase of platelet aggregation See PRECAUTIONS) This may be reflected in altered bleeding time Bruising, hematoma tormation and frank hemorrhagge have been reported Relatıve lymphocylosis and hypohave also been reported Anema and bone marrow suppres. sion have been re00*ted

Hepatic: Minor elevations of iransaminases (eg SGOT and SGPT) and LOH are frequent and appear to bc dose related. Occasionally, laboratory tests also show increases in serum bilirubin and abnormal changes in other liver function tests.
These results may reflect potentially serious hepatotoxicity These results may
(See WARNINGS)

Melabolic: Hyperatmorem a (See PRECAUTIONS) Hyperglycinemia has been eported and associated wilh a tatai outcome in a

Pancreatic: These have been reports of acute pancreatitis occurring in association witn therapy w th valproc acid.

Other: Edema of the extretit es has beer reported

DOSAGE ANO ADMINISTRATION The recommended in lial dosage is $15 / \mathrm{mg} / \mathrm{kg} /$ day. Increasing at one week intervals by prec uce further increases.

The maximal recommended dosage is $60 \mathrm{mg} / \mathrm{kg} / \mathrm{cay}$. Wren the to:al daily dose exceeds $125 \mathrm{mg}$, it should the giver in a divided tegumen (See Table)

The frequency of adverse effects iparticularly glevated liver enzymes) may increase with increasing dose. Therefore, the benefit gained by improving seizure controf must be weighed against the increased incidence of adverse effects.
As the dosage is raised blood levels of phenobatbital or phenyton may be alfected (See PRECAUTIONS)

Patients who experience $G$ I irritation may benefit from administration of the drug with lood of by a progressive increase of the dose from an intlial low
should be swallowed without chewing.

AVAILABILITY Epival (divalproex sodium) enteric-coated tablets are available as salmon-pink coloured tablets of $12 \mathrm{~s} \mathrm{mg} \mathrm{suppliec}$
in bontles of 100 tablets, peach-coloured tablets of $250 \mathrm{mg}$ arc iavender-colout
and 500 taslets

Table ol Initial Doses by Weight (based on $15 \mathrm{mg} / \mathrm{kg} /$ day)

\begin{tabular}{|c|c|c|c|c|c|}
\hline \multicolumn{2}{|c|}{ Weighl } & \multirow{2}{*}{$\begin{array}{l}\text { Tolal daily } \\
\text { dose imgi) }\end{array}$} & \multirow{2}{*}{\multicolumn{3}{|c|}{$\begin{array}{l}\text { Dosage (mg) } \\
\text { Equivalent to valproic acid } \\
\text { Dose } 1 \text { Dose } 2 \text { Dose } 3\end{array}$}} \\
\hline $\mathrm{kg}$ & 10 & & & & \\
\hline 10.24 & 22.5 & 25 & 125 & 0 & 125 \\
\hline 25.39 .9 & $55 \cdot 8$ & 50 & 25 & 0 & 250 \\
\hline 40.59 .9 & 88.131 & 750 & 25 & 250 & \\
\hline 60.74 .9 & $132-164.9$ & 1,000 & 250 & 250 & 500 \\
\hline 75.8 & $165 \cdot 197.9$ & 1.250 & 500 & 250 & 500 \\
\hline
\end{tabular}

Produc: Monograpt ara table on 'equest.

References: 1. Oreituss FE, Langer DH. Side eftects of vaiproate Am J Med 1988:84 (supph 1A) $34.41 \quad$ 2. Dean CJ Valproate In

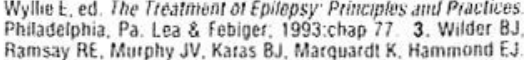
Ramsay RE, Murphy JV. Katas BJ, Marquatdt K. Hammond EJ.
Comparison of valproic acid and pherytoin in nevily diagnosed Comparison of valproic acid and pherytoin in nevily diagnosed
tome-clanic seizures. Neurology $1983: 33: 1474-6$. 4. furntull DM. Howel $D$. Aawlins MD. Chadwick DW. Which drug for the aduli epileptic pattent: phenytom or valproate 7 Br Med J 1985:290:815-9. . Sodium valproale: monother.

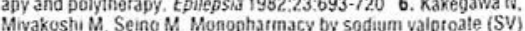
and the blood concentration. In. Program and anstracts of the XI Epiltepsy Interuatiunal Symposium. September 30, 1979. Fitenzo. thaly. Abstract. 153. 7. Epival (divaloroetx sodlum) Ptoduct Monograph. Abboll taboratories, Limited 8. Wilter BJ. Rangel RJ. Review of valproate monotherapy in the ireatment of generalized
tonic-clonic seizutes. Am $J$ Med $1988: 84$ (suppl $A$ ) $7-13$. $-M @$ Apooll Labo alcries imi:ed

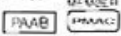




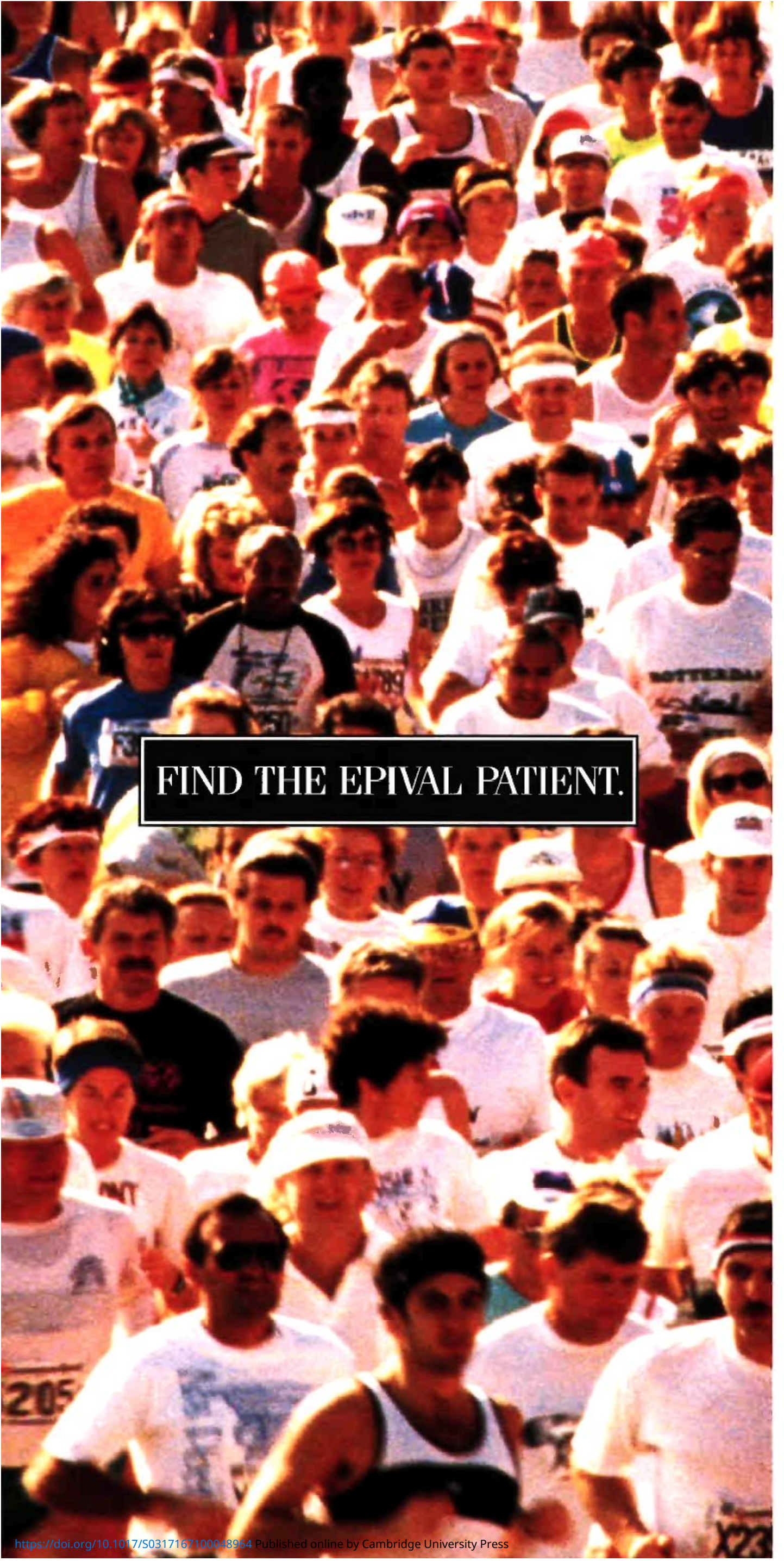

Epival

For Control Over

Daily Living.

With Epival, epileptic patients can

appear "just like anyone else."

Epival has been associated with little

effect on learning and cognition.

It is effective in primary generalized

epilepsy $y^{2-4}$ as well as in partial seizures that secondarily generalize. ${ }^{36 . t}$ And it is generally well tolerated, ${ }^{7}$ causing less GI irritation (nausea, vomiting and indigestion) than valproic acid. ${ }^{8}$

Prescribe Epival — by name only to help restore your patients' control over daily living.

Because there's more to anticonvulsant therapy than seizure control.

Write it by name only...

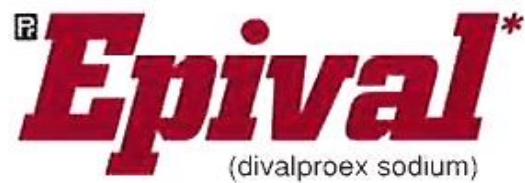

Helps put patients back in control.

tFor use as sole or adjunctive therapy in the treatment of simple or complex absence seizures, including pett mal and is useful in primary generalized seizures with tonic-clonic manifestations. EPIVAL may aiso be used adjunctively in patients with multiple selzure types which include either absence or tonic-clonic seizures

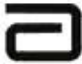

pharmaceutical paoducta Divioion ABBOTT LaBohatoRIES, LIMII
SAINT-LALAENT, QUEEEE:

Product Monogragh available on request

•TM (1) Abbott Laboratories, Limited

Printed in Canada 